\title{
TESTING STATIC TRADEOFF THEORY AGAINST PECKING ORDER MODELS OF CAPITAL STRUCTURE IN NIGERIAN QUOTED FIRMS
}

\author{
W. A. ADESOLA \\ (Received 29, January 2009; Revision Accepted 20, April 2009)
}

\begin{abstract}
We test two models with the purpose of finding the best empirical explanation for corporate financing choice of a cross section of 27 Nigerian quoted companies. The models were developed to represent the Static tradeoff Theory and the Pecking order Theory of capital structure with a view to make comparison between theoretical predictions and empirical results. Data pertaining to 1996 through 2006 were used. By using ordinary least square multiple regression methods, we aim at establishing which of the two theories has the best explanatory power for Nigerian firms. The analysis of the outcomes led to the conclusion that both of them appears to be a good description of the financing policies of those firms for the period under review.
\end{abstract}

KEYWORDS: Capital Structure, Pecking Order, Trade-off theory, Quoted Firms, Policies

\section{$1.0 \quad$ INTRODUCTION}

The determining factors affecting the choice of the capital structure of firms can be broken down into four categories, according to their purpose towards:

(a) Improving the conflicts between the various stakeholders with claims upon the firm resources, machines, managers (the agency approach):

(b) Conveying private information to the capital markets or mitigating effects of adverse selection. (the asymmetric information approach)

(c) influencing the nature of products or competition in the product/input market s: and

(d) Influencing the results of disputes over corporate control (Harris and Ravir 1991).

Financing policy by firms requires managers to identify ways of finding new investment. The managers may exercise three main choices: use retained earnings borrow through debt instruments, or issue new shares. Hence the standard capital structure of a firm includes retained earnings, debt and equity; these three components of capital structure reflect firm's ownership by shareholders while the second component represents ownership by debt holders. The pattern found in developing and developed countries alike (see Eboh, 2004 la-porta, lepez-de silence and shleifer, 1999)

The choice of appropriate capital structure is seen by many as a viable option to increase and maximize shareholders wealth. With the recent development in the Securities and Exchange Commission (SEC), Nigerian stock exchange (NSE), and the entire financial system, with firms being listed and quoted in the NSE, one issue that has received great attention is the capital structure decision. This follows because the market value of the firm may be affected by the capital structure decision. The debt-equity mix has implications for the shareholders earning and risk, which in turn will affect the cost of capital and the market value of the firm. The term capital structure is used to represent debt/equity mix.

Factors influencing firms in their decision on a certain capital structure has been cause for debate for decades among academics. Several theories have been put forward on the subject, but it seems consensus is yet to be reached. Among

W. A. Adesola, Department of Computer Science, Cross River University of Technology, Calabar 
those, there is the Static Tradeoff Theory (STT), which asserts that firms decide for a predetermined capital structure and try to stick to it through time, although they might eventually deviate from it for a various reasons. Another well known theory in the literature is the Pecking Order Theory (POT), which states that the firms' capital structure is determined by the difference between the internally generated cash flow and the financial deficit.

Recently, an interesting discussion has been generated in studies designed to detect which of these two theories of capital structure best describes the financing choice of corporations. To date, just a very few studies had been performed in this area; (see Shyam-Sander and Myers (1999), Chirinko and Singha (2000), Frank and Goyal (2003) using European, USA and Asia data. In Nigeria, very little work has been done in this area, see Odedokun (1995), Olatundun (2002) and Eboh (2004). Thus there is a conspicuous gap in the empirical research on capital structure theories in Nigeria, this gap request urgent attention.

\subsection{Objectives of the study}

The main or general objective of this study is to test the static trade off theory and the pecking order theory using Nigerian data in order to establish which theory best explains the capital structure of local firms.

\subsection{LITERATURE REVIEW}

\section{$2.1 \quad$ Theoretical Frameworks}

The literature in capital structure began with the seminar work by Modigliani and Miller (1958) on the irrelevance of capital structure. Since then, capital structure continues to be a topic of interest in financial economics and had produced a large volume of research. Modigliani Miller theory with its modifications is based on the assumption of a perfect capital market. This is followed by the trade off theory which emanated from the works of De Angelo and Masulis (1990). According to this theory, the tax advantage of debt will be traded off against the cost of financial distress. This trade off results in an optimal capital structure. The third theory is the pecking order theory. This theory implies that firms prefer to finance using retained earnings, followed by debt, and finally by equity see Myers and Majluf (1984).

One theory that has generated strong empirical support is agency theory, Agency theory posits that capital structure is determined by agency cost i.e. cost due to conflicts of interest. The literature in this area has been built on the early work by Fama and miller (1972) and Jensen and Meckling (1976). These alternative theories lead to different conclusion regarding the influence of capital structure decision on corporate financing choice.

\subsubsection{The Static Trade-off Theory}

The static trade off theory of capital structure predicts that firms will choose their mix of debt and equity financing to balance the cost and benefits of debt. It should however be realized that a company cannot continuously minimize its overall cost of capital by employing debt. A point or range is reached beyond which debt becomes more expensive because of the increased risk(financial distress) of excessive debt to creditors as well to shareholders. When the degree of leverage increases, the risk of creditor increases, the risk of creditors increases and they demand a higher interest rate and do not grant loan to the company at all, once it's debt has reached a particular level. Further the excessive amount of debt makes the shareholders position very risky. This has the effort of increasing the cost of equity. Thus up to a point the overall cost of capital decreases with debt, but beyond that point the cost of capital would start increasing and , therefore it would not be advantageous to employ debt further, so there is a combination of debt and equity which minimizes the firm's average cost of capital and maximizes the market value per share. The trade-off between cost of capital and earnings per share (EPS) set the maximum limit to the use of debt. However, other factors should also be evaluated to determined the appropriate capital structure for a company. According to the trade off theory, the tax advantages of debt will be traded off against the costs of financial distress firms for which the tax advantage is lower (e.g. firms with non-debt tax shields) and firms with higher costs of financial distress (e.g. firms with more relative earnings) will have lower leverage (see De Angelo and Masulis (1980)). As debt financing causes monitoring by lenders and reduces the free cash flow, debt can be used as an instrument to align the interest of managers and shareholders (Jensen and Meckling (1976)), Jensen (1986)). However, debt financing may also cause conflicts of interests between shareholders and creditors, which could e.g. lead to sub optimal investment policies.

\subsubsection{Pecking Order Theory}

The major prediction of the model is that firms will not have a target optimal capital structure, but will instead follow a pecking order of incremental financing choices that places internally 
generated funds at the top of the order, followed by debt issues, and finally only when the firm reached its "debt capacity" new equity financing.

yers and Majluf (1984) noted that this theory is based upon costs derived from asymmetric information between managers and the market and the idea that trade-off theory costs and benefits to debt financing are of issuing new securities. The cost of equity includes the cost of new issue of shares and the cost of retained earnings. The cost of debt is cheaper than the cost of both these sources of equity funds. Considering the cost of new issue and retained earnings, the latter is cheaper because personal taxes have to be paid by shareholders on distributed earnings while no taxes are paid on retained earnings as also no floatation costs are incurred when the earnings are retained. As a result, between the two sources of equity funds, retained earnings are preferred. It has been found in practice that firms prefer internal financing. If the internal funds are not sufficient to meet the investment outlays, firms go for external finance, issuing the safest security first. They start with debt, then possible hybrid securities such as convertible debentures, then perhaps equity as a last resort. There are other theories, such as Modigliani and miller's and also those based on agency theory.

\subsection{Empirical Literatures}

Many studies have been performed on capital structure issues in developed countries (especially US and some European countries), but to our knowledge very few has been done on developing countries in general. This section therefore reviews some of the relevant ones as follows;

In the cross sectional study of the determinants of capital structure, Rayan and Zingales (1995) examine the extent to which at the level of the individual firm; the capital structure may be explained by four key factors, namely; market-tobook, size, profitability and tangibility. Their analysis is performed upon a firm-level sample from each of the countries, and although the results of their regression analysis differ slightly across countries, they appear to uncover some fairly strong conclusion.

Rayan and Zingales used the market-tobook ratio as a proxy for the level of growth opportunities available to the enterprise. This is in common with most studies; tend to apply proxies rather than valuation models to estimate growth opportunities (Danbolt et al (1995)). Rayan and Zingales suggest that, this is consistent with the theoretical predictions of Jensen and Meckling
(1976) on agency theory, and the work of Myer (1977), who argues that, due to information asymmetries, companies with high gearing would have a tendency to pass up, while companies with large amounts of investment opportunities (also known a growth options) would tend to have low gearing ratios.

However, the empirical evidence regarding the relationship between gearing and growth opportunities is rather mixed. While Titman and Wessels (1995) found a negative correlation Kester (1986) does not find support for the predicted negative relationship between growth opportunities and gearing. Despite this controversy, however, Rayan and Zingales (1995) uncovered evidence of negative correlation between market-to-book and gearing for all countries. This is thus consistent with the hypothesis of Jensen and Meckling (1976), Myers (1977), and lends weight to the notion that companies with high level of growth opportunities can be expected to have low level of gearing.

Secondly, Rajan and Zingales include size (which is proxied by the natural logarithm for sales) in their cross sectional analysis. There is no clear theory to provide expectations as to be effect which size should have on gearing.

$$
\text { Shyam-Sander and Myers }
$$

introduced a test of pecking order theory of capital structure. Their test is based upon the prediction of what type of financing is used to fill the "financing deficit". The financing deficit is defined using the cash flow identity, as the growth in assets less the growth in current liabilities (except the current portion of long-term debt) less the growths in retained earnings. According to this identity, this deficit must be "filled" by the net sale of new securities. Shyam-Sander and Myers ague that, except for firms at or near their debt capacity, the pecking order predicts that the deficits will be filled entirely with new debt issues. The empirical expectation of their test is $D D_{i t}=B_{p o} D E F i t+E_{i t}$. Where $D D_{\text {it }}$ is the net debt issued by firm $i$ in period $t$, and $D E F_{i t}$ is the corresponding financial deficit. Shyam-Sander and Myers argue that the "Sample" version of the pecking order predict $=0$ and $\beta_{\mathrm{po}}=$ 1. Intuitively, the slope coefficient in this regression indicates the extent to which debt issues cover the financing deficit, they acknowledge that $\beta_{\text {po }}$ may be less than 1 for firms. Near their debt capacity, behaviour, the firms in their sample should not be significantly constrained by such concerns. They find $\beta_{\mathrm{po}}=0.75$ with an $R^{2}$ of 0.68 . They interpret this as evidence that "the pecking order is an excellent first-order description of corporate financing behaviour for the sample. They also find 
that a target adjustment model based on the tradeoff theory has little power to explain the changes in debt financing for these firms.

This paper has generated an interesting discussion in the literature of capital structure. First, Chirinko and Singha (2000) were among the first to criticize Shyam-Sander and Myers through illustration using several examples that their test has no power to distinguish between plausible alternative hypotheses.

Frank and Goyal (2003) also question the conclusion drawn by Shyam-Sander and Myers (1999) on several fronts. The most interesting challenges are the extent to which the ShyamSunder and Myers findings hold for broader sample of firms, whether the results hold over a longer time horizon (in particular including the 1990s) and whether their findings hold for subsamples of firms with high level of asymmetric information. For their broader sample of firms, Frank and Goyal show that the prediction $\beta_{p o}=1$ does not hold and that it significantly weakens in the 1990's, even for the types of firms (large, mature) examined by Shyam-Sunder and Myers (1999)

Fama and French (2002) examined many of the predictions of the tradeoff and the pecking order theories with respect to capital structure and dividend policy. They argue that for the majority of the predictions, the two theories agree and generally report findings consistent with these shared predictions. Consistent with Shyam-Sander and Myers (1999), Fama and French (2002) find that (for their large sample) debt is used to address variations in investment and earnings in the short term. However, they also find, as in Frank and Goyal (2003), that small; high-growth companies issue most of the equity (see Fama and French (2002)). Fama and French join Frank and Goyal in arguing that these findings contradict the pecking order theory.

The only major attempt on Nigeria using Nigerian data known to us is the one by Eboh (2004), he survey a cross section of 65 Nigerian quoted companies in bid to identify the predominant capital structure theory that influence financing choice of firms in Nigeria; he discovers among others that the pecking order theory of Myers and Majluf appears to be a good description of the financing policies of a large sample of firm within the period (1996-2000).

The understanding of the factors that resulted in these contrasting finding is important furthering our understanding of capital structure and financing choices by firms.

\subsection{METHODOLOGY}

\subsection{Sources of Data}

The data for this study were derived from secondary sources. The researcher opted for secondary data because of the nature of this research. The data were extracted from publications of the Nigerian Stock exchange factbook 2001, 2005 and 2007 editions, Best Shares Selection Guide various publications published by Flarmark and Company, Security and Exchange Commission (SEC) annual reports. The data contains all the hundred and forty five companies quoted on the Nigeria Stock Exchange as at 2007. However, only annual report of 27 companies has all the data that is required for this study. Samples cover 15 sectors of NSE classifications namely: Automobile and Tyre, Banking, Breweries, Building Materials, Chemical and Paints, Conglomerates, Construction, Engineering Technology, Food/Beverages and Tobacco, Health care, Industrial/Domestic product, Insurance, Petroleum Marketing, Printing and Publishing, Textiles.

\subsection{Model Specification}

The following models were built in line with the hypotheses of the study.

1. $\mathrm{CS}_{21}=\mathrm{f}\left(\mathrm{TANG}_{21}, \mathrm{ROA}_{21}, \mathrm{SZ}_{21}\right)$

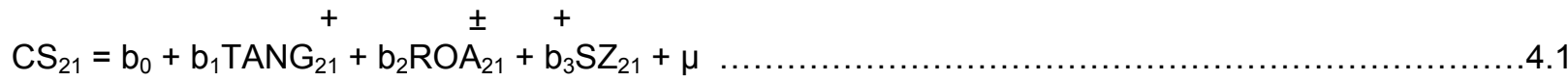

2. $\mathrm{CS}_{22}=\mathrm{f}\left(\mathrm{TANG}_{22}, \mathrm{ROA}_{22}, \mathrm{SZ}_{22}, \mathrm{GRT}_{22}\right)$

$$
\mathrm{CS}_{22}=\mathrm{b}_{0}+\mathrm{b}_{1} \mathrm{TANG}_{22}^{+}+\stackrel{+}{+}+\stackrel{+}{\mathrm{b}_{2} \mathrm{ROA}_{22}}+\mathrm{b}_{3} \mathrm{SZ}_{22}+\mathrm{b}_{4} \mathrm{GRT}_{22}+\mu
$$

3. $\mathrm{CS}_{23}=\mathrm{f}\left(\mathrm{TANG}_{23}, \mathrm{ROA}_{23}, \mathrm{SZ}_{23}\right)$

$$
\mathrm{CS}_{23}=\mathrm{b}_{0}+\mathrm{b}_{1} \mathrm{TANG}_{23}+\mathrm{b}_{2} \mathrm{ROA}_{23}+\mathrm{b}_{3} \mathrm{SZ}_{23}+\mu
$$




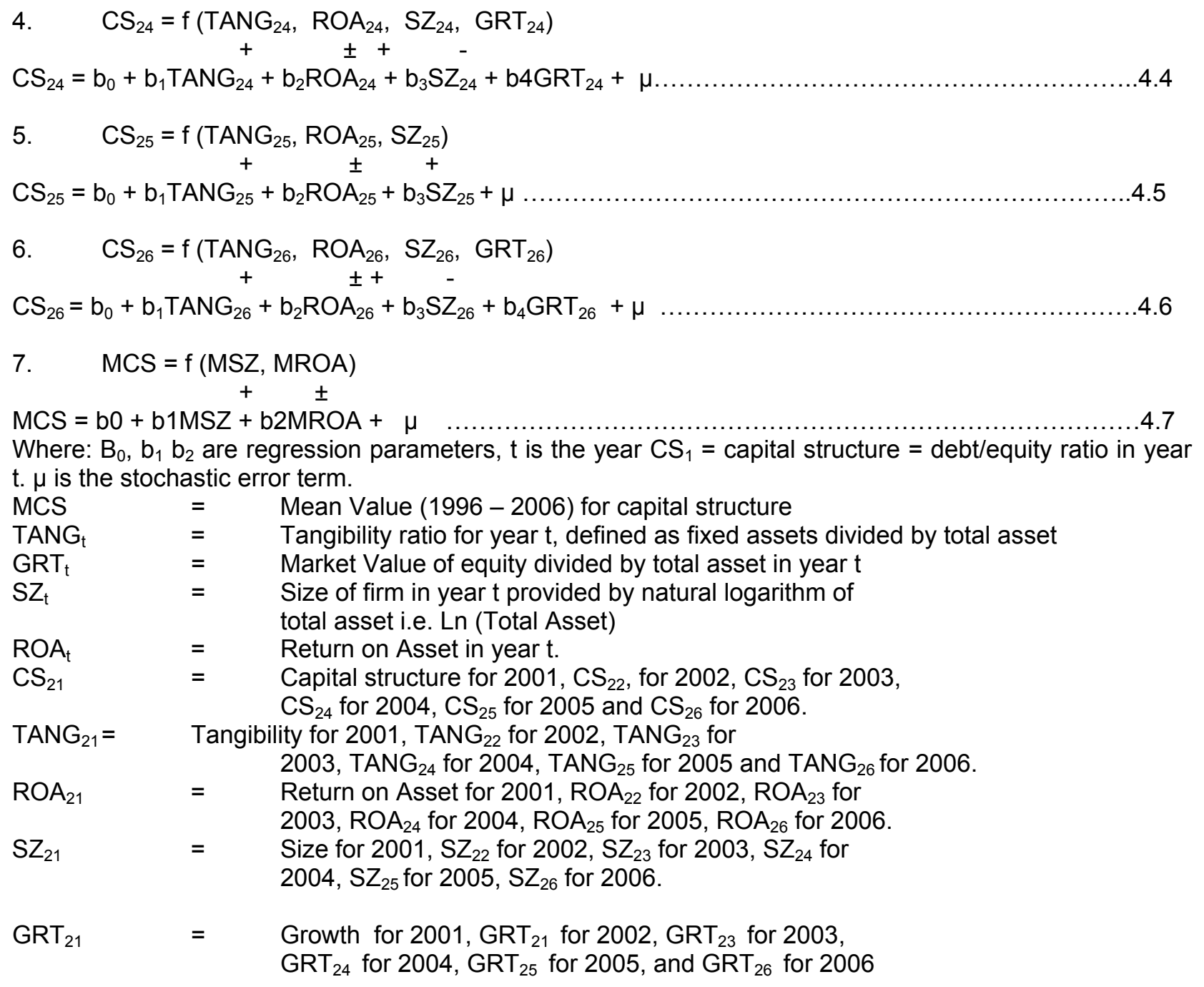

\subsection{EMPIRICAL RESULTS AND ANALYSIS}

The analysis is done on equation basis,

\section{Equation 4.1}

CS21 $=0.859-0.299$ TANG21 + 2.780 ROA21 - 5.7E-02SZ21

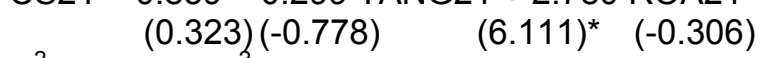

$R^{2}=64.6 \% \quad R^{2}($ adj $)=59.6 \%$ F-stats $=12.801 \quad D W=2.713$

\section{Equation 4.2}

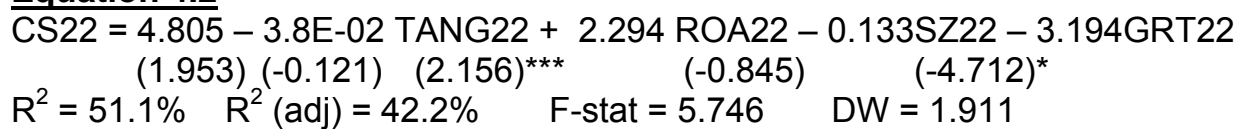

\section{Equation 4.3}

CS24 $=4.009+0.173$ TANG24 -1.115 ROA24 + 4.487E-02SZ24 - 4.349GRT24

$\begin{array}{ccccc}(0.814) & (0.518) & (-0.765) & (0.155) & (-2.760)^{* *} \\ R^{2}=34.2 \% & R^{2}(\operatorname{adj})=22.3 \% & \text { F- stat }=2.864 & \text { DW }=1.990\end{array}$

\section{Equation 4.4}

$$
\begin{aligned}
& \text { MCS }=134.339-5.754 \mathrm{MSZ}-12.507 \mathrm{MROA}
\end{aligned}
$$

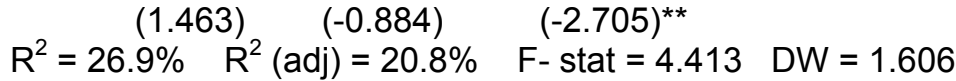


The numbers in bracket represents t- value, while the number directly beneath the bracket represents the parameter estimates. *indicate that the estimated co-efficient is statistically significant at $1 \%$ level of significant, ${ }^{* *}$ indicate that the estimate co-efficient is statistically significant at 5 per cent level of significance while ${ }^{* * *}$ indicate that the estimated co-efficient is statistically significant at 10 per cent level of significance.

In equation 4.1, We regress tangibility in 2001 (TANG21), return on asset in 2001 (ROA21), and size in 2001 (SZ21) on the capital structure for 2001. the equation shows a good explanatory power of the independent variable. The co-efficient of multiple determination $\left(\mathrm{R}^{2}\right)$ of 0.646 or $64.6 \%$ indicates that about $64.6 \%$ variations in the observed behaviour in the dependent variable is jointly explained by the independent variables. The remaining $35.4 \%$ may better be accounted for by other omitted variables and is represented by the stochastic error term. The high $\mathrm{R}^{2}$ indicates that the model fits the data well and is statistically robust.

The F- statistic of 12.801 is significant at $1 \%$ level considering the table $F$ - statistic $\left[F_{0.01}\right.$ $(3,6)=9.78]$. The calculated F- statistic is greater than the table F- statistic (i.e $12.801>9.78$ ), therefore it is significant at $1 \%$ level. This buttresses the fact that the high $\mathrm{R}^{2}$ is better than would have occurred by chance. On the test of significance, the table t- statistic, two tailed test, with degree of freedom N-K = 10- $4=6$, the following correspond to $10 \%, 5 \%$ and $1 \%$ significance levels respectively: $1.943,2.447$ and 3.707. Any parameter that is less than the above figures (the least being the $10 \%$ level) is statistically insignificant in the model; and therefore, could as well be removed from the model and the overall goodness of fit $\left(R^{2}\right)$ may not be significantly affected as stated in koutsoyannis (1977). A cursory examination of the equation shows that only return on asset in 2001 (ROA21) is significant at $1 \%$ level. The other independent variable failed the test of significance in the model. The ROA21 carries a positive sign and this is consistent with the Trade off theory of capital structure in 2001. On the contrary, tangibility of asset (TANG21) and logs of asset (SZ21) are not statistically significant; which means that statistically, they have no significant influence on the capital structure in 2001. Another essential test is the second order or econometric criteria. The DW statistic is 2.713. the table DW at $5 \%$ level indicates the following, given $\mathrm{K}^{1}=3$ (excluding the constant term) and sample size $(\mathrm{n})$ equals 10 . then $\mathrm{dL}=0.525$, dU= 2.016, 4-dU $=1.984$ and $4-\mathrm{dL}=$
3.475. The decision rule is: if calculated DW falls within the dU and $4-\mathrm{dU}$, then the result of the model are fantastic, reliable and have no serial correlation in the residuals of the model; therefore there is no autocorrelation. If it lies within $\mathrm{dU}$ and $\mathrm{dL}$ or $4-\mathrm{dU}$ and $4-\mathrm{dL}$, then the result are inconclusive. But beyond the above mentioned regions, result is critical and therefore have autocorrelation. In such a case the result of the estimates will no longer be reliable for prediction and need transformation of the original model to solve the econometric problem. The DW statistics (2.713) show inconclusive evidence regarding the presence or absence of positive first order serial correlation.

In equation 4.2, We state that the capital structure in 2002 (CS22) is a function of tangibility in 2002 (TANG22), return on asset in 2002 (ROA22), size in 2002 (SZ22) and growth in 2002 (GRT22). Testing the expected signs of the parameter estimates, we observe that three estimates, tangibility, size and growth are wrongly signed. On the contrary, the coefficient of the constant term and return on asset ROA22 are correctly signed, showing that the two variables are directly related to the capital structure in 2002 . The equation shows a good explanatory power of the independent variable with a coefficient of multiple determination of $51.1 \%$. the F- statistic of 5.746 is significant ay $5 \%$ level. $F_{\text {calculated }}>\mathrm{F}$ tabulated at $5 \%$ level i.e $(5.746>5.19)$

On the test of significance, only two parameter estimates are significant. They are return on asset (ROA22) at 10\% level and growth(GRT22) at 1\% level of significance. The return on asset carries a positive sign which is consistent with the trade- off theory of capital structure while growth with a negative sign signifies the pecking order theory of Myers and Majluf (1984).

Based on the DW test, there is no incidence of auto- correlation in this equation, since the DW calculated (1.911) lies between the dU (2.414) and 4 - dU (1.586). Therefore, our estimates are reliable.

In equation 4.3, We regress tangibility in 2004 (TANG24), return on asset in 2004 (ROA24), size in 2004 (SZ24), growth in 2004 (GRT24) on the capital structure in 2004 (CS24).

Testing the expected signs of the parameter estimates, we observed that two estimates, return on asset and growth are wrongly signed: The coefficient of multiple determination $\left(R^{2}\right)$ of $34.2 \%$ does not show a very impressive explanatory power of the independent variables. 
The F - statistic of 2.864 is statistically significant only at $25 \%$ level of significant which is not impressive. On the test of significance, only the growth (GRT24) parameter is significant at $5 \%$ level of significance. All the other variables failed the failed the test of significant in the model. The GRT24 carries a negative sign which is consistent with the pecking order theory of Myers and Majluf (1984). Based on the DW statistic, there is no incidence of autocorrelation in this model. The DW calculated is 1.990 and this lies in the region between dU (2.414) and $4-\mathrm{dU}$ (1.586). Therefore our estimates are reliable.

In equation 4.4, We test for the stability of the results over time; by finding the average result within the ten years period of this study i.e. (1996 2006, excluding 1998), so as to form better judgment and generalization from the result of the test. The equation considers mean of capital structure (MCS) as a function of mean of size (MSZ) and mean of return on asset (MROA).

On the test of significance, only the mean of return on asset (MROA) is statistically significant at $5 \%$. All the other variable failed the test of significance in the model. The coefficient of mean of return on asset has a negative sign supporting the economic a priori expectation by pecking order theory of Myers and Majluf: specifically, MROA comes out with an estimated coefficient of -12.507 . This means that an increase of one percent in MROA will decrease the MCS by 12.507 . This test confirms that the mean of return on capital structure is explained by the mean on the return on asset. This is in agreement with pecking order theory. The F- statistic of 4.413 is significant at 10 per cent level. The $\mathrm{F}$ calculated $>\mathrm{F}$ tabulated at 10 per cent level i.e $(4.413>3.26)$. The DW statistic of 1.606 shows inconclusive evidence regarding the presence or absence of positive first- order serial correlation.

\subsection{DISCUSSION OF FINDINGS}

The main findings of this study are:

1. That in 2001, return on asset ROA21 is the significant determinant of capital structure which confirms the fact that the Trade off theory as tested by ROA21 exert the only significant influence on the capital structure of firm. The influence of the pecking order theory as tested by the negative relationship between return on assets ROA21 and capital structure is statistically insignificant.

2. That in 2002, the positive return on asset which test for the trade off theory influence the capital structure. However it is also observed that negative growth which is used in testing the agency theory exerts a significant influence on the capital structure in 2002. Although negative growth is a consistent test for the pecking order theory of capital structure.

3. That our result is inconclusive about which of the two theories among pecking order theory and trade off theory exerts the most dominant effect on capital structure on Nigeria quoted firms during the period under review between. This is evident from equation 4.4 in which the average return on asset (MROA) is negative and is also the only significant determinant of capital structure in this model. This is consistent with the pecking order theory as against the other equation which supports the trade off theory as having domineering influence on the variation of capital structure in those years. Thus, our various equations have shown that the capital structure theories do actually influence corporate financing choice in Nigeria.

4. That our result is inconsistent with the findings of Myers and Majluf (1984) as supported by Clagget (1991) and Eboh (2004) that the main determinant of capital structure is log of asset (SZ) but rather we found return on asset to be the main determinant of capital structure in the period under review (1996- 2006).

\subsection{CONCLUDING REMARKS}

The leading conclusion is that capital structure of quoted firms in Nigeria are significantly influenced by the return on asset and growth which is proxied by market value of equity divided by book value of assets and not size proxied by natural logarithm of total asset during the period of study is inconsistent with the previous work in this area by Eboh (2004). Our empirical result, support both pecking order theory and static trade off theory as playing significant role in corporate financing choice of quoted firms but with the pecking order exerting more influence as reported in the average capital structure equation used in testing the stability of our result over the ten years period of study.

Other relevant conclusions are as follows:

i. Tangibility defined as ratio of fixed asset to total asset and size do not influence the capital structure. This is inconsistent with the result found by Hall and Michael (2000) 
in a study of three thousand U.K companies.

ii. The influence of agency theory as tested by growth variable is strong and significant.

Based on our empirical result and major findings obtained from the result, we wish to recommend the following.

1. That the Nigeria capital market be depended and well structured to removed information asymmetries between firm managers and the capital market, and also eliminate imperfections in the market in order to improve the confidence and integrity of the system.

2. That in order to optimize corporate financing choice in Nigeria; both the constituent of Trade off theory and Pecking order theory should be utilized in capital structure decision of firm since both of them exert an influence on Nigerian firms.

3. That firms should consider other relevant factor such as: concern for dilution of control, desire to maintain operating flexibility, ease of marketing, agency and bankruptcy costs, capacity for economies of scale and long run survivability of the firm; when taking their capital structure decision and not just rely on pecking order and trade off theory in their financing choice.

\section{REFERENCES}

Chirinko, R.S and Singha, A. R., 2000. "Testing Static Trade- off against Pecking Order Models of Capital Structure; A Critical Comment", Journal of Financing Economics_(58): pp.417- 425.

Clagget, E. T., 1991. "Capital Structure: Convergent and pecking order Evidence", Journal of Financial Economics, (1): p. 3548.

De Angelo, H. and Masulis, R. W., 1980. Optimal Capital Structure under Coporate and Personal Taxation", Journal of Financial Economics, (8): pp. 3- 29

De Medeiros, O.R and Daher, C. E., 2004. "Testing static tradeoff against pecking order models of Capital structure in Brazilian firms", Paper presented at the XXVIII ENANPAD Sept. 25-29, Curitiba Brazil.
Eboh, D. C., 2004. The Influence of Capital structure theories on corporate financing choice in Nigeria.(Unpublished MSc thesis).

Fama, E., 1980, "Agency Problems and Theory of the Firm", Journal of Political Economics. Friend, I. and Hasbrouck, I. (1988), "Determinants of Capital Structure", in J. Chen research in finance, London: JAI Press.

Fama, E.F. and French, K.R., 2002. "Testing tradeoff and Pecking order Prediction about Dividends and debts", Review of Financial Studies, (15): p.1-33

Frank, M.Z. and Goyal, V. K., 2003. "Test the Pecking order theory of Capital structure", Journal of Financial Economics, 67: p. 217- 248.

Hall, G.H.P and Micheal, N., 2000. "Industry effect on unquoted SMEs Capital structure", International Journal of Economics and Business, 7, (3): p. 297-312.

Harris, M. and Raviv, A., 1991. "Capital Structure and the Information Role of Debt, Journal of Finance, 45: pp. $321-349$.

Jensen, M. C., 1986: "Agency Cost of free cash flows, Corporate Finance and Take-Over", American Ecoomic Review, 76: p. 323339.

Jensen, M. C. and Meckling, W.H., 1976. “ Theory of the Firm: Managerial Behaviour, Agency Costs and Ownership Structure", Journal of Financial Economics, 3:.

Kester, C.W., 1986. "Capital and Ownership Structure: A comparison of United States and Japanese manufacturing corporations", Financial management, 15: p. 5-16.

La-Porta, R. Lopez de Silanes, F. and Shleifer, A., 1999. "Corporate Ownership around the World", Journal of Finance, 54: 2, April, pp. 471517.

Modigliani, F. and Miller, M.H., 1958. "The Cost of Capital, Corporation Finance and the theory of Investment", American Economic Review, 48 (3): pp. 261-297. 
Myers, S. C., 1977. "Determinants of Corporate Borrowing" The Journal of Financial Economics, (5): pp. 147-175.

Myers, S. C., 1984. "The Capital Structure Puzzle," Journal of Finance, (34): pp. 55

Myers, S. C. and Majluf, N.S., 1984. "Corporate Financing and Investment Decisions which have information that investors do not have ," Journal of Financial Economics, p. 187-221.

Odedokun, M.O., 1995. "Dividend policy, Investment Spending and Financing decisions: Evidence from Nigeria quoted non-financial firms" Nigeria Journal of Economics and Social Studies. 37, (3): pp. 185-201.
Olatundun, O., 2002. "Mortgage processing in FMBN", FMBN Journal Lagos, (3): p. 2634.

Shyam-Sanders, L. and Myers, S.C., 1999. "Testing Static trade-off against pecking order Models of Capital structure", Journal of Financial Economics, (51): pp.14211460.

Rajan, R.G and Zingales, L., 1995. "What do we know about Capital Structure? Some evidence from international data", The Journal of Finance, (50): Issue 5, p.14211460.

Titman, S. and Wessels, R., 1988. "The determinants of Capital Structure Choice", The Journal of Finance, 43, (1): pp.1-19. 


\section{APPENDIX A: Sample quoted firms variables}

\begin{tabular}{|c|c|c|c|c|c|c|c|c|}
\hline Company & Year & FIXED ASSET & ROA & TANG & PBT & $\begin{array}{l}\text { TOTAL } \\
\text { ASSET }\end{array}$ & DEBT & EQUITY \\
\hline \multirow{10}{*}{$\begin{array}{c}1 . \\
\text { AUTOMOBILE } \\
\text { AND TYRE } \\
\text { DUNLOP NIG } \\
\text { PLC }\end{array}$} & 996 & 558554 & 0.508282 & 0.650287 & 436,581 & 858,934 & 7,508 & 168,000 \\
\hline & 1997 & 842660 & 0.467594 & 0.803666 & 490,282 & $1,048,519$ & 40,000 & 252,000 \\
\hline & 1999 & 831509 & 0.023611 & 0.452094 & 43,428 & $1,839,236$ & 660,910 & $1,474,993$ \\
\hline & 2000 & 773889 & 0.133064 & 0.638458 & 161,290 & $1,212,121$ & 786,832 & $1,546,528$ \\
\hline & 2001 & 1026767 & 0.158748 & 0.796108 & 204,743 & $1,289,733$ & 533,347 & $1,667,478$ \\
\hline & 2002 & 1236221 & 0.111117 & 1.029430 & 133,438 & $1,200,878$ & 766,425 & $1,526,235$ \\
\hline & 2003 & 2848225 & -0.305429 & 3.150778 & $-276,101$ & 903,975 & $-179,655$ & $1,292,525$ \\
\hline & 2004 & 4771829 & -0.693175 & 8.116073 & $-407,551$ & 587,948 & $-1,307,723$ & $1,090,301$ \\
\hline & 2005 & 10996684 & -0.052842 & 2.794335 & $-207,953$ & $3,935,349$ & $-2,380,155$ & $4,872,776$ \\
\hline & 2006 & 12995123 & -0.100925 & 1.883261 & $-696,421$ & $6,900,327$ & $5,365,178$ & $8,127,686$ \\
\hline \multirow{10}{*}{$\begin{array}{l}\text { 2. (BANKING) } \\
\text { ACCESS BANK } \\
\text { NIG PLC }\end{array}$} & 1996 & 71198 & 0.024006 & 0.060532 & 28,236 & $1,176,203$ & 667,167 & 100,000 \\
\hline & 1997 & 6183 & 0.023210 & 0.034774 & 41,251 & $1,777,256$ & $1,195,009$ & 100,000 \\
\hline & 1999 & 144284 & 0.022180 & 0.029580 & 108,187 & $4,877,256$ & $2,732,604$ & 600,000 \\
\hline & 2000 & 540041 & 0.019751 & 0.064027 & 166,594 & $8,434,560$ & $4,400,596$ & 841,750 \\
\hline & 2001 & 736217 & 0.014459 & 0.0917066 & 116,081 & $8,027,957$ & $7,108,464$ & 919,493 \\
\hline & 2002 & 890230 & 0.001582 & 0.078483 & $\begin{array}{l}-17,947 \\
\end{array}$ & $11,352,941$ & $9,399,157$ & $1,943,784$ \\
\hline & 2003 & 1400052 & 0.0305897 & 0.061998 & 810,639 & $22,582,040$ & $20,216,683$ & $2,365,356$ \\
\hline & 2004 & 1843687 & 0.030367 & 0.058825 & 951,750 & $31,341,507$ & $28,638,677$ & 2,830 \\
\hline & 2005 & 2417425 & 0.011223 & 0.036125 & 751,033 & $66,918,315$ & $52,846,391$ & 1,924 \\
\hline & 2006 & 3953161 & 0.006413 & 0.022647 & $1.119,449$ & $174,553,866$ & $145,659,980$ & $28,893,886$ \\
\hline \multirow{10}{*}{$\begin{array}{c}3 . \\
\text { (BREWERIES) } \\
\text { GUINESS NIG } \\
\text { PLC }\end{array}$} & 1996 & 3665981 & 0.128122 & 0.800452 & 586,787 & \begin{tabular}{|r|}
$4,579,887$ \\
\end{tabular} & 426,871 & 70,000 \\
\hline & 1997 & 7613279 & 0.155369 & 0.808700 & $1,462,682$ & $9,414,217$ & - & 250,734 \\
\hline & 1999 & 6530376 & 0.419373 & 0.703272 & $3,894,179$ & $9,285,698$ & - & 353,982 \\
\hline & 2000 & 6530376 & 0.500043 & 0.703272 & $4,643,251$ & $9,285,698$ & $-2,087,137$ & $10,681,154$ \\
\hline & 2001 & 7350320 & 0.529910 & 0.688157 & $5,660,054$ & $10,681,154$ & $-2,366,338$ & $12,663,140$ \\
\hline & 2002 & 7945542 & 0.462082 & 0.627454 & $5,851,413$ & $12,663,140$ & $-2,138,282$ & $14,157,810$ \\
\hline & 2003 & 12723046 & 9378 & 8659 & $9,901,668$ & $14,157,810$ & $-5,034,014$ & $15,189,428$ \\
\hline & 2004 & 16012252 & 9449 & 4170 & $11,687,494$ & 9,428 & $-5,892,322$ & $16,908,244$ \\
\hline & 2005 & 29179564 & 4325 & 0858 & $6,276,167$ & $18,227,442$ & $-5,548,363$ & 27,442 \\
\hline & 2006 & 29531969 & 5965 & 9789 & $11,436,771$ & $20,947,782$ & $-6,968,521$ & $25,667,544$ \\
\hline \multirow{10}{*}{$\begin{array}{c}4 . \\
\text { (BREWERIES) } \\
\text { NIGERIAN } \\
\text { BREWERIES }\end{array}$} & 1996 & & & & 1,465 & $14,057,025$ & - & 57,500 \\
\hline & 1997 & & & &, 396 & $14,662,903$ & - & 57,500 \\
\hline & 1999 & & & & $5,268,116$ & $16,779,413$ & - & $16,779,413$ \\
\hline & 2000 & 12074011 & 1630 & 5573 & $6,256,916$ & $24,865,477$ & $12,822,406$ & $-24,865,477$ \\
\hline & 2001 & 15287003 & 0.297230 & 0.606696 & $7,489,351$ & $25,197,125$ & $13,068,092$ & $-25,197,125$ \\
\hline & 2002 & 37022763 & 0.452681 & 1.614218 & $10,382,429$ & $22,935,410$ & $-10,718,921$ & $-22,935,410$ \\
\hline & 2003 & 50014941 & 0.419756 & 1.910964 & $10,992,047$ & $26,186,746$ & $-16,752,267$ & $-26,186,746$ \\
\hline & 2004 & 54448027 & 0.323782 & 1.927094 & $9,148,138$ & $28,253,944$ & $-16,511,021$ & $-28,253,944$ \\
\hline & 2005 & 52428880 & 0.371433 & 1.509863 & $12,897,746$ & $34,724,241$ & $-7,391,506$ & $-34,724,241$ \\
\hline & 2006 & 46677917 & 0.453421 & 1.287688 & $16,436,255$ & $36,249,393$ & 880,854 & $36,249,393$ \\
\hline \multirow{10}{*}{$\begin{array}{l}\text { 5. (BUILDING } \\
\text { MATERIALS) } \\
\text { ASHAKA } \\
\text { CEMENT PLC }\end{array}$} & 1996 & 765395 & 0.422649 & 0.412717 & 783,814 & $1,854,526$ & 3,827 & 292,500 \\
\hline & 1997 & 812609 & 0.397849 & 0.352564 & 916,983 & $2,304,850$ & 3,827 & 292,500 \\
\hline & 1999 & 867859 & 0.295905 & 0.291052 & 882,330 & $2,981,799$ & 3,121 & $2,784,799$ \\
\hline & 2000 & 1152358 & & & $1,334,592$ & $3,525,848$ & - & $3,287,435$ \\
\hline & 2001 & & & & $2,792,578$ & $4,999,844$ & - & $4,705,149$ \\
\hline & 2002 & & & & $2,093,071$ & $5,992,502$ & - & $5,700,938$ \\
\hline & 2003 & & & & $3,135,497$ & $6,637,252$ & - & $6,324,108$ \\
\hline & 2004 & & & & $4,892,887$ & $7,556,687$ & - & $7,218,717$ \\
\hline & 2005 & & & & $6,519,249$ & $8,293,207$ & - & $11,633,603$ \\
\hline & 2006 & & & & $4,951,464$ & $7,198,831$ & - & $11,618,084$ \\
\hline $\begin{array}{l}\text { 6. (BUILDING } \\
\text { MATERIALS) }\end{array}$ & 1996 & 6685070 & 0.051907 & 34.610410 & 10,026 & 193,15 & $100,000,0$ & 43,65 \\
\hline
\end{tabular}




\begin{tabular}{|c|c|c|c|c|c|c|c|c|}
\hline \multirow{9}{*}{$\begin{array}{c}\text { CEMENT } \\
\text { COMPANY OF } \\
\text { NORTHERN } \\
\text { NIGERIA }\end{array}$} & 1997 & 3802456 & 0.049684 & 18.095989 & 10,440 & 210,127 & $87,500,000$ & 65,675 \\
\hline & 1999 & 3492819 & -0.120533 & 5.621809 & $\mid-74,887$ & 621,298 & $41,666,667$ & 678,479 \\
\hline & 2000 & 3080411 & -1.692403 & 10.665984 & $-488,778$ & 288,807 & $-588,434$ & 265,890 \\
\hline & 2001 & 917617 & -2.148913 & 1.852791 & $-1,064,275$ & 495,262 & $-1,329,414$ & 195,262 \\
\hline & 2002 & 1062659 & -0.571209 & 0.908167 & $\begin{array}{c}- \\
668,380\end{array}$ & $1,170,114$ & $-2,067,220$ & 579,886 \\
\hline & 2003 & 2074289 & -0.093759 & 2.083362 & $-93,351$ & 995,645 & $-2,648,768$ & 675,716 \\
\hline & 2004 & 2160468 & 0.507385 & 1.297141 & 845,081 & $1,665,561$ & $-3,508,387$ & $1,406,438$ \\
\hline & 2005 & 2140175 & 0.233917 & 1.331854 & 375,886 & $1,606,914$ & $-4,328,601$ & $1,606,914$ \\
\hline & 2006 & & & & - & & $-4,328,601$ & $1,606,914$ \\
\hline \multirow{10}{*}{$\begin{array}{l}\text { 7. (CHEMICAL } \\
\text { AND PAINTS) } \\
\text { BERGER } \\
\text { PAINTS NIG } \\
\text { PLC }\end{array}$} & 1996 & 20527 & 1.327119 & 0.356941 & 76,320 & 57,508 & 116,553 & 6,418 \\
\hline & 1997 & 36361 & 1.263524 & 0.491411 & 93,492 & 73,993 & 146,626 & 115,003 \\
\hline & 1999 & 146292 & 1.560188 & 4.186949 & 54,513 & 34,940 & 120,514 & $2,098,077$ \\
\hline & 2000 & 144861 & 0.089982 & 0.344122 & 37,879 & 420,958 & 23,109 & $1,569,923$ \\
\hline & 2001 & 213166 & 0.292342 & 0.458482 & 135,921 & 464,938 & 38,718 & 227,089 \\
\hline & 2002 & 250502 & 0.250657 & 0.479918 & 130,835 & 521,968 & 81,538 & 439,323 \\
\hline & 2003 & 235573 & 0.297086 & 0.416529 & 168,021 & 565,562 & 103,545 & 460,533 \\
\hline & 2004 & 279571 & 0.274918 & 0.461864 & 166,411 & 605,310 & 106,961 & 496,385 \\
\hline & 2005 & 1278937 & 0.064750 & 1.211655 & $-68,346$ & $1,055,529$ & 223,408 & 883,924 \\
\hline & 2006 & 1251050 & 0.096369 & 1.092195 & 110,386 & $1,145,445$ & 105,605 & 965,293 \\
\hline \multirow{10}{*}{$\begin{array}{c}8 . \\
\text { (CONGLOMER } \\
\text { ATES) } \\
\text { CHELLARAMS } \\
\text { PLC }\end{array}$} & 1996 & 538829 & 2.208226 & 1385.164524 & 859 & 389 & 508,821 & 5,805 \\
\hline & 1997 & 198584 & 1.418848 & 14.242558 & 19,783 & 13,943 & 186,460 & 548,417 \\
\hline & 1999 & 338395 & 1.227914 & 11.511208 & 36,097 & 29,397 & 284,579 & 470,101 \\
\hline & 2000 & 352547 & 0.034437 & 0.381667 & 31,810 & 923,703 & - & 914,567 \\
\hline & 2001 & 452782 & 0.037646 & 0.448358 & 38,018 & $1,009,867$ & - & 990,114 \\
\hline & 2002 & 497387 & 0.045574 & 0.483162 & 46,916 & $1,029,440$ & - & $1,009,370$ \\
\hline & 2003 & 936117 & 0.056275 & 0.778837 & 67,640 & $1,201,941$ & - & $1,037,103$ \\
\hline & 2004 & 1279630 & 0.059140 & 0.826608 & 91,553 & $1,548,049$ & - & $1,437,195$ \\
\hline & 2005 & 1326728 & 0.064717 & 0.813164 & 105,591 & $1,631,562$ & - & $1,458,788$ \\
\hline & 2006 & 1931010 & 0.048726 & 0.875288 & 107,497 & $2,206,140$ & - & $2,051,402$ \\
\hline \multirow{10}{*}{$\begin{array}{c}9 . \\
\text { (CONGLOMER } \\
\text { ATES) JOHN } \\
\text { HOLT PLC }\end{array}$} & 1996 & 1623 & 0.124329 & 0.000791 & 255,000 & $2,051,000$ & 154,000 & 195,000 \\
\hline & 1997 & 1621 & 0.165632 & 0.000773 & 347,000 & $2,095,000$ & 68,000 & 195,000 \\
\hline & 1999 & 2100 & 3.768518 & 0.004861 & $-1,628,000$ & 432,000 & 82,000 & 367,000 \\
\hline & 2000 & 1951 & 0.097328 & 0.003723 & 51,000 & 524,000 & $1,408,000$ & 483,000 \\
\hline & 2001 & 2048 & 0.222222 & 0.001763 & 258,000 & $1,161,000$ & 881,000 & $1,116,000$ \\
\hline & 2002 & 2632 & 0.138207 & 0.001317 & 276,000 & $1,997,000$ & 596,000 & $1,952,000$ \\
\hline & 2003 & 2868 & 0.066901 & 0.001442 & $-133,000$ & $1,988,000$ & 868,000 & $1,971,000$ \\
\hline & 2004 & 3478 & 0.094122 & 0.001336 & 245,000 & $2,603,000$ & 863,000 & $2,603,000$ \\
\hline & 2005 & 2922 & 0.006744 & 0.001313 & 15,000 & $2,224,000$ & 503,000 & $2,224,000$ \\
\hline & 2006 & 3536 & 0.162700 & 0.001530 & 376,000 & $2,311,000$ & $1,005,000$ & $2,311,000$ \\
\hline \multirow{10}{*}{$\begin{array}{c}10 . \\
\text { (CONGLOMER } \\
\text { ATES) UAC OF } \\
\text { NIG PLC }\end{array}$} & 1996 & 6609100 & 0.147709 & 0.842739 & $1,158,400$ & $7,842,400$ & 20,400 & 868,400 \\
\hline & 1997 & 8319800 & 0.068101 & 0.969199 & 584,600 & $8,584,200$ & 25,000 & 817,700 \\
\hline & 1999 & 3685900 & -0.108739 & 0.668340 & $-599,700$ & $5,515,000$ & 10,800 & $4,321,000$ \\
\hline & 2000 & 4347700 & 0.048113 & 0.751378 & 278,400 & $5,786,300$ & 512,000 & $4,507,000$ \\
\hline & 2001 & & 0.103533 & & 805,800 & $7,783,000$ & $1,555,400$ & $5,365,000$ \\
\hline & 2002 & 9101800 & 0.163790 & 1.020735 & $1,460,500$ & $8,916,900$ & $1,562,600$ & $6,429,000$ \\
\hline & 2003 & 9587600 & 0.137699 & 0.852792 & $1,548,100$ & $11,242,600$ & $1,835,600$ & $7,920,000$ \\
\hline & 2004 & 9824000 & 0.129534 & 0.669022 & $1,902,100$ & $14,684,100$ & $1,671,200$ & $11,150,000$ \\
\hline & 2005 & 11232000 & 0.169523 & 0.652442 & $2,918,400$ & $17,215,300$ & $2,069,400$ & $14,180,253$ \\
\hline & 2006 & 10748700 & 0.153760 & 0.540407 & $3,058,300$ & $19,890,000$ & $1,200,000$ & $16,099,218$ \\
\hline \multirow{7}{*}{$\begin{array}{c}11 . \\
\text { (CONGLOMER } \\
\text { ATES) } \\
\text { UNILEVER } \\
\text { NIGERIA PLC }\end{array}$} & 1996 & 2400984 & 0.435410 & 0.544719 & $1,919,179$ & $4,407,742$ & 56,863 & 504,440 \\
\hline & 1997 & 2586598 & 0.021295 & 0.597268 & $-92,223$ & $4,330,714$ & 56,863 & 504,440 \\
\hline & 1999 & 2615223 & -0.144245 & 0.635024 & 594,046 & $4,118,301$ & 332,112 & $3,659,733$ \\
\hline & 2000 & 2934680 & 0.371554 & 0.842145 & $1,294,780$ & $3,484,765$ & 332,112 & $3,484,765$ \\
\hline & 2001 & 3598035 & 0.385912 & 0.875633 & $1,585,738$ & $4,109,065$ & 984,844 & $4,109,065$ \\
\hline & 2002 & 4498208 & 0.492623 & 1.079311 & $2,053,089$ & $4,167,664$ & $1,222,697$ & $4,167,664$ \\
\hline & 2003 & 4822861 & 0.711325 & 1.234873 & $2,778,116$ & $3,905,550$ & $1,713,043$ & $3,905,550$ \\
\hline
\end{tabular}




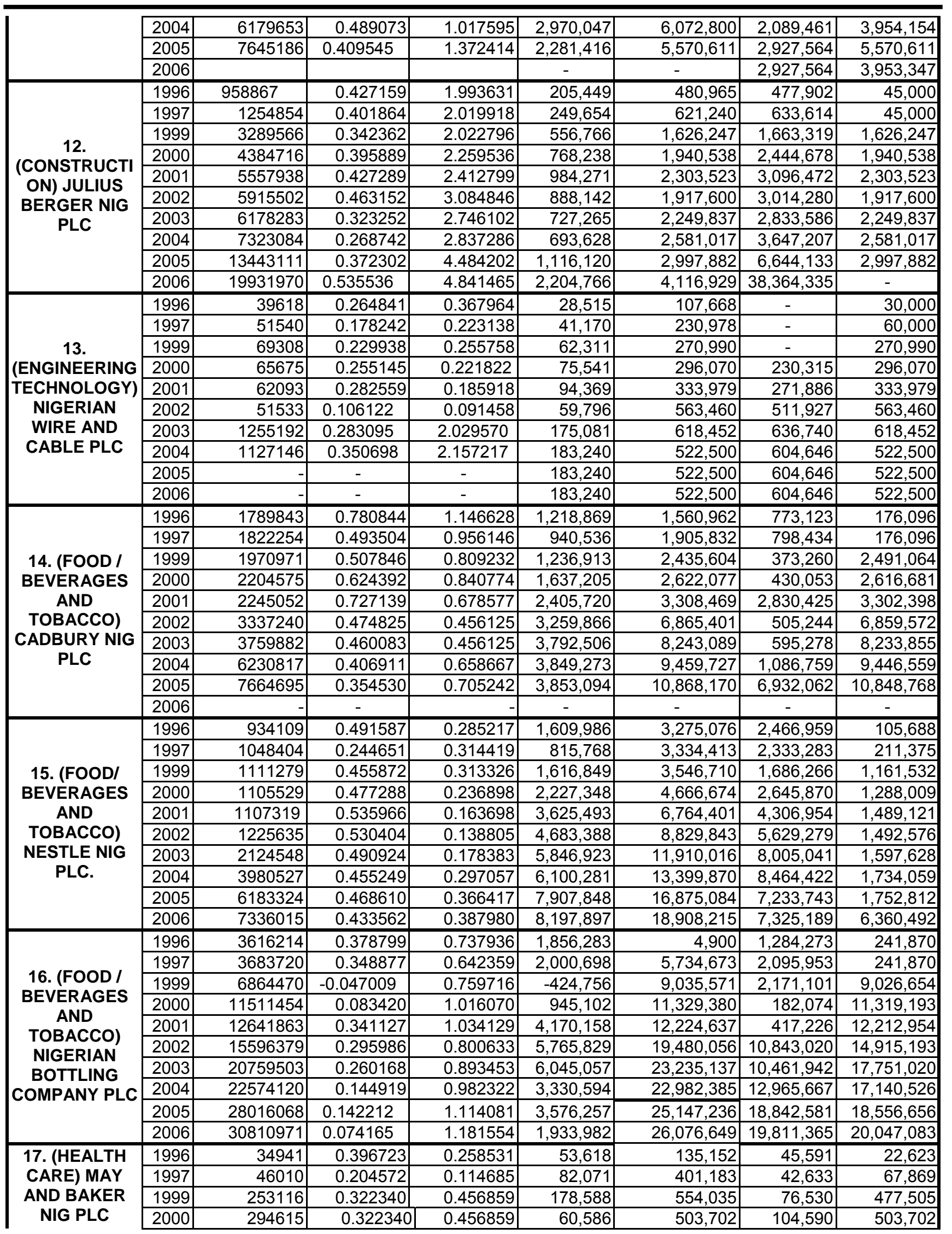




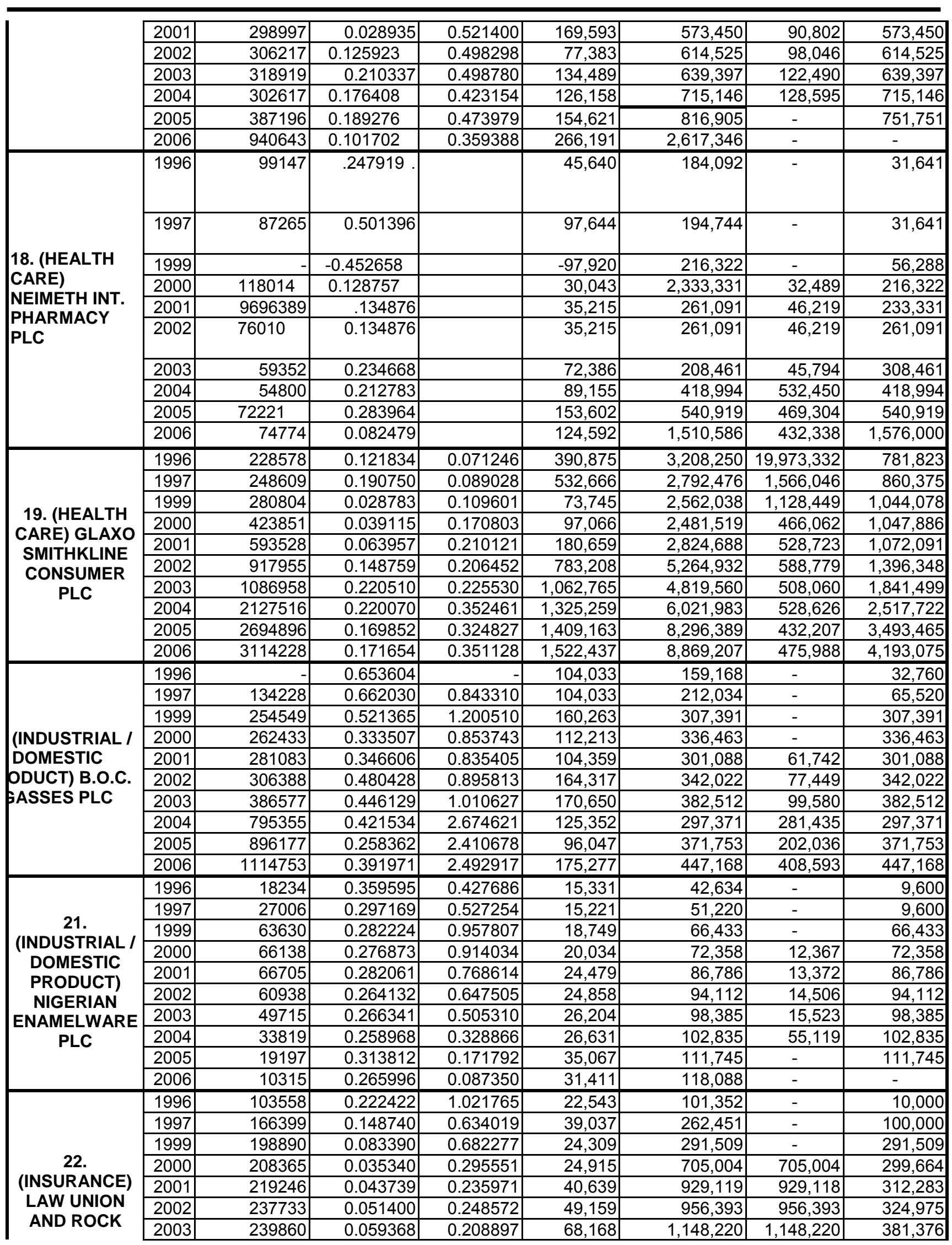




\begin{tabular}{|c|c|c|c|c|c|c|c|c|}
\hline \multirow{5}{*}{$\begin{array}{l}\text { INSURANCE } \\
\text { PLC }\end{array}$} & 2004 & 226832 & 0.01854 & 0.161398 & \begin{tabular}{|l|}
$-16,661$ \\
\end{tabular} & $1,405,412$ & $1,405,412$ & 648,876 \\
\hline & 2005 & & - & - & \begin{tabular}{l|l}
- & \\
\end{tabular} & - & - & $1,091,474$ \\
\hline & & & & & & & & \\
\hline & & & & & & & & \\
\hline & 2006 & & - & & - & - & - & - \\
\hline \multirow{10}{*}{$\begin{array}{c}23 . \\
\text { (INSURANCE) }\end{array}$} & 1996 & 748274 & 0.023053 & 0.535439 & 29,465 & $1,278,141$ & 124,193 & 40,000 \\
\hline & 1997 & 827672 & 0.025013 & 0.659040 & 31,414 & $1,255,874$ & 186,143 & 70,000 \\
\hline & 1999 & 973319 & 0.034465 & 0.418106 & 80,232 & $2,327,921$ & 476,863 & 738,212 \\
\hline & 2000 & 1023104 & 0.040036 & 0.361808 & 113,214 & $2,827,753$ & 334,280 & 770,006 \\
\hline & 2001 & 1.165363 & 0.039078 & 0.326028 & 139,683 & $3,574,424$ & 488,564 & $1,124,176$ \\
\hline & 2002 & 1141378 & 0.033278 & 0.215526 & 176,235 & $5,295,776$ & 920,982 & $1,181,275$ \\
\hline & 2003 & 1281998 & 0.026754 & 0.178493 & 192,160 & $7,182,325$ & 820,496 & $1,240,517$ \\
\hline & 2004 & 1311826 & 0.034589 & 0.159028 & 285,332 & $8,248,983$ & 690,364 & $1,877,980$ \\
\hline & 2005 & 1316939 & 0.037218 & 0.156760 & 312,672 & $8,400,982$ & 712,895 & $2,089,427$ \\
\hline & 2006 & 1344908 & 0.0065818 & 0.120566 & 734,196 & $11,154,881$ & 700,030 & $5,487,465$ \\
\hline \multirow{10}{*}{$\begin{array}{c}24 . \\
\text { (PETROLEUM } \\
\text { MARKETING) } \\
\text { MOBIL OIL NIG. } \\
\text { PLC }\end{array}$} & 1996 & 1644867 & 1.727347 & 2.271009 & $1,251,099$ & 724,289 & 333,764 & 72,119 \\
\hline & 1997 & 2539003 & 0.893750 & 2.602720 & 871,871 & 975,519 & 147,729 & 72,119 \\
\hline & 1999 & 3092725 & 1.115262 & 1.599501 & $2,156,422$ & $1,933,555$ & 173,770 & $1,933,855$ \\
\hline & 2000 & 31572293 & 0.391771 & 2.335137 & 529,706 & $1,352,080$ & 333,517 & $1,018,563$ \\
\hline & 2001 & 3998799 & 1.328161 & 2.550352 & $2,082,478$ & $1,567,940$ & 881,857 & 686,083 \\
\hline & 2002 & 4756097 & 0.517544 & 2.964112 & 830,431 & $1,604,560$ & $\begin{array}{l}918,477 \\
\end{array}$ & 686,083 \\
\hline & 2003 & 5224948 & 1.056279 & 2.545609 & $2,165,048$ & $2,052,533$ & $1,366,450$ & 686,083 \\
\hline & 2004 & 5760218 & 0.985461 & 2.656053 & $1,985,461$ & $2,168,713$ & $1,286,162$ & 882,551 \\
\hline & 2005 & 5913176 & 0.645102 & 1.123958 & $3,393,903$ & $5,261,028$ & $1,955,947$ & $3,305,081$ \\
\hline & 2006 & 7134964 & 0.514920 & 1.449010 & $2,535,481$ & $4,924,024$ & $2,090,346$ & \\
\hline \multirow{10}{*}{$\begin{array}{c}25 . \\
\text { (PETROLEUM } \\
\text { MARKETING) } \\
\text { CHEVRON OIL } \\
\text { NIG PLC } \\
\text { (FORMERLY } \\
\text { TEXACO) }\end{array}$} & 1996 & 905786 & 0.729826 & 1.269199 & 520,853 & 713,667 & $2,323,138$ & 56,694 \\
\hline & 1997 & 888756 & -0.204080 & 1.903346 & $-95,294$ & 466,944 & $3,014,194$ & 75,592 \\
\hline & 1999 & 1035949 & 1.608134 & 1.358411 & $1,226,392$ & 762,618 & $4,520,099$ & 762,618 \\
\hline & 2000 & 1434760 & 1.611362 & 1.508779 & $1,532,311$ & 950,941 & $4,199,697$ & 950,941 \\
\hline & 2001 & 2130757 & 1.017149 & 1.895740 & $1,143,247$ & $1,123,971$ & $6,619,487$ & $1,123,971$ \\
\hline & 2002 & 2559923 & 0.998003 & 1.644482 & $1,553,566$ & $1,556,674$ & $6,584,756$ & $1,556,674$ \\
\hline & 2003 & 2600906 & 0.824688 & 1.295876 & $1,655,202$ & $2,007,063$ & $\begin{array}{r}10,242,44 \\
7\end{array}$ & $2,007,063$ \\
\hline & 2004 & 3219636 & 0.464210 & 1.137075 & $1,314,415$ & $2,831,506$ & $\begin{array}{r}12,762,76 \\
5\end{array}$ & $2,831,506$ \\
\hline & 2005 & 3620662 & 0.571366 & 1.162269 & $1,779,903$ & $33,115,166$ & $\begin{array}{r}10,109,13 \\
9 \\
\end{array}$ & $3,115,166$ \\
\hline & 2006 & 3951386 & 0.546987 & 1.166819 & $1,852,352$ & $3,386,459$ & $\begin{array}{r}12,708,24 \\
5\end{array}$ & $3,386,459$ \\
\hline \multirow{10}{*}{$\begin{array}{l}\text { 26. (PRINTING } \\
\text { AND } \\
\text { PUBLISHING) } \\
\text { LONGMAN NIG } \\
\text { PLC }\end{array}$} & 1996 & 99882 & 285614 & 954 & 40,353 & 141,285 & 7,435 & 35,000 \\
\hline & 1997 & 104456 & 0.220118 & 0.712391 & 32,276 & 146,630 & 7,435 & 35,000 \\
\hline & 1999 & 158944 & 0.428618 & 1.039413 & 65,543 & 152,917 & 17,436 & 152,917 \\
\hline & 2000 & 175054 & 0.539578 & 0.720502 & 111,770 & 207,143 & 17,436 & 189,707 \\
\hline & 2001 & 188918 & 0.292885 & 0.647689 & 96,391 & 262,203 & 32,884 & 229,319 \\
\hline & 2002 & 170703 & 0.292885 & 0.647689 & 77,192 & 263,557 & 29,043 & 234,514 \\
\hline & 2003 & 168507 & 0.358786 & 0.570359 & 51,964 & 295,440 & 45,964 & 249,476 \\
\hline & 2004 & 152677 & 0.358786 & 0.489565 & 111,892 & 311,862 & 36,174 & 275,690 \\
\hline & 2005 & 189372 & 0.421782 & 0.460635 & 173,399 & 411,110 & 54,930 & 351,433 \\
\hline & 2006 & 210837 & 0.457838 & 0.340418 & 283,561 & 619,347 & 64,163 & 555,184 \\
\hline \multirow{7}{*}{$\begin{array}{l}\text { 27. (TEXTILE) } \\
\text { UNITED NIG } \\
\text { PLC }\end{array}$} & 1996 & 5466864 & 0.146034 & 0.788368 & $1,012,663$ & $6,934,402$ & 502,052 & 205,632 \\
\hline & 1997 & 5315176 & 0.101211 & 0.761591 & 706,362 & $6,979,035$ & 64,590 & 246,758 \\
\hline & 1999 & 5040341 & 0.100056 & 0.655335 & 769,560 & $7,691,234$ & 32,247 & $6,289,603$ \\
\hline & 2000 & 5006003 & 0.087167 & 0.693034 & 629,640 & $7,223,307$ & $1,037,175$ & $5,591,875$ \\
\hline & 2001 & 7178103 & 0.073765 & 0.586372 & 903,006 & $12,241,532$ & $2,162,836$ & $9,235,454$ \\
\hline & 2002 & 7071027 & 0.123011 & 0.551736 & $1,576,683$ & $12,817,344$ & $2,207,374$ & $10,003,955$ \\
\hline & 2003 & 6775027 & 0.026656 & 0.538799 & 335,184 & $12,574,302$ & $2,333,896$ & $9,644,724$ \\
\hline
\end{tabular}




\begin{tabular}{|l|r|c|r|r|r|r|r|}
\hline 2004 & 6883708 & 0.027265 & 0.551248 & 340,475 & $12,487,478$ & $2,202,162$ & $9,713,363$ \\
\hline 2005 & 6302122 & 0.018970 & 0.484766 & 246,626 & $13,000,338$ & $2,630,842$ & $9,812,662$ \\
\hline 2006 & 5825521 & -0.016126 & 0.445303 & $-210,965$ & $13,082,122$ & $3,239,789$ & $9,016,410$ \\
\hline
\end{tabular}

Source: Author's computation, stock exchange factbook 2001, 2005 and 2007 edition, BSSG Issue Number 3 \& 9.

$\mathrm{ROA}=$ Return on asset

TANG = Tangibility

PBT $=$ Profit before Tax

\section{APPENDIX B: REGRESSION RESULTS}

Table A: Standard Multiple Regression Result for equation 4.1

\begin{tabular}{|l|c|c|c|}
\hline Regressor & Coefficient & Standard Error & t-ratio \\
\hline (Constant) & 0.859 & 2.657 & 0.323 \\
\hline TANG21 & -0.299 & 0.385 & -0.778 \\
\hline ROA21 & 2.780 & 0.455 & 6.111 \\
\hline SZ21 & $-5.7 \mathrm{E}-02$ & 0.185 & -0.306 \\
\hline
\end{tabular}

Dependent Variable: CS21

R_Square $=0.646$ Adj. $R \_$Square $=0.596$ SER $=1.284046$

F_statistics $=12.801 \mathrm{DW}$-Statistics $=2.713$

Source: Research results compiled from the secondary data.

Table B: Standard Multiple Regression Result for equation 4.2

\begin{tabular}{|l|c|c|c|}
\hline Regressor & Coefficient & Standard Error & t-ratio \\
\hline (Constant) & 4.805 & 2.461 & 1.953 \\
\hline TANG22 & $-3.8 \mathrm{E}-02$ & 0.316 & -1.121 \\
\hline ROA22 & 2.294 & 1.064 & 2.156 \\
\hline SZ22 & -0.133 & 0.158 & -0.845 \\
\hline GRT22 & -3.194 & 0.678 & -4.712 \\
\hline
\end{tabular}

Dependent Variable: CS22

R_Square $=0.511 \quad$ Adj. R_Square $=0.422 \quad$ SER $=1.125266$

F_statistics $=5.746$ DW-Statistics $=1.911$

Source: Research results compiled from the secondary data.

Table C: Standard Multiple Regression Result for equation 4.3

\begin{tabular}{|l|c|c|c|}
\hline Regressor & Coefficient & Standard Error & t-ratio \\
\hline (Constant) & 4.009 & 4.927 & 0.814 \\
\hline TANG24 & 0.173 & 0.335 & 0.518 \\
\hline ROA24 & -1.115 & 1.457 & -0.765 \\
\hline SZ24 & $4.487 \mathrm{E}-02$ & 0.290 & 0.155 \\
\hline GRT24 & -4.349 & 1.576 & -2.760 \\
\hline
\end{tabular}

Dependent Variable: CS24

R_Square $=0.342$ Adj. R_Square $=0.223 \quad$ SER $=2.122880$

F_statistics $=2.864$ DW-Statistics $=1.990$

Source: Research results compiled from the secondary data. 
Table D: Standard Multiple Regression Result for equation 4.4

\begin{tabular}{|l|c|c|c|}
\hline Regressor & Coefficient & Standard Error & t-ratio \\
\hline (Constant) & 134.339 & 91.839 & 1.463 \\
\hline MSZ & -5.754 & 6.513 & -0.884 \\
\hline MROA & -12.507 & 4.624 & -2.705 \\
\hline
\end{tabular}

Dependent Variable: MCS

R_Square $=0.269 \quad$ Adj. R_Square $=0.208 \quad$ SER $=62.58751$

F_statistics $=4.413$ DW-Statistics $=1.606$

Source: Research results compiled from the secondary data. 